\title{
Micropropagation of Stirlingia latifolia (Proteaceae), an Important Cut Flower from Western Australia
}

\author{
Eric Bunn and Kingsley W. Dixon \\ Kings Park and Botanic Garden, West Perth, Western Australia 6005 \\ Australia
}

Additional index words. activated charcoal, microcuttings, blueboy, ornamental

Stirlingia latifolia (R. Br.) Steudel is the most popular wild-picked Proteaceae in Western Australia, accounting for 1.5 million stems annually in 1981 (Burgman and Hopper, 1982). The recalcitrance of blueboy to conventional seed or cutting propagation methods has precluded the plant from commercial horticulture. This paper outlines a method for micropropagation of S. latifolia with application for mass production of the species on a commercial scale.

Shoot tips 20 to $30 \mathrm{~mm}$ long were taken in midspring (October) from mature, actively growing plants in the field and agitated for $5 \mathrm{~min}$ in $0.05 \%$ Tween- 80 detergent, then surface sterilized in $2 \% \mathrm{NaOCl}$ for $5 \mathrm{~min}$. The shoots $(50)$ were then trimmed to $10 \mathrm{~mm}$ in length, rinsed thoroughly in three changes of sterile distilled water, and placed upright in 30-ml-capacity polycarbonate tubes (with closures) containing $10 \mathrm{ml}$ of half-strength Murashige and Skoog (1962) basal salts with $100 \mu \mathrm{M}$ sodium-ferric EDTA, $1 \mu \mathrm{M}$ thiamine $\mathrm{HCl}, 60 \mathrm{mM}$ sucrose, $500 \mu \mathrm{M}$ myoinositol, pH 6.0, and agar at $10 \mathrm{~g} \cdot$ liter $^{-1}$. Media were autoclaved at $121 \mathrm{C}$ for $15 \mathrm{~min}$, sloped to cool, and one explant was placed in each tube. Twenty-four percent of initial explants were sterile and were multiplied on half-strength MS medium supplemented with $\mathrm{N}$ - (phenylmethyl)-1 $\mathrm{H}$ - purine-6-amine (BA) or $N$ - (3-methyl-2 butenyl)-1 $H$ - purine-6-amine (2iP) under cool-white fluorescent lamps with light intensity of $40 \mu \mathrm{mol} \cdot \mathrm{m}^{-2} \cdot \mathrm{s}^{-1}$ at culture level and 16/8 h light/dark. Shoots were incubated for 4 to 5 weeks and shoot multiplication was assessed after the fourth and fifth successive incubation periods. On medium supplemented with $5 \mu \mathrm{M} 2 \mathrm{iP}$ most explants multiplied by 7-fold, and on medium supplemented with $0.5 \mu \mathrm{M}$ BA most explants multiplied by $\geq 9$-fold (Table 1). BA at $1 \mu \mathrm{M}$ induced prolific basal shoot production, but shoots seldom grew longer than 5

Received for publication 27 June 1990. Accepted for publication 20 Sept. 1991. We thank Bob Dixon and nursery staff of Rings Park and Botanic Garden. The cost of publishing this paper was defrayed in part by the payment of page charges. Under postal regulations, this paper therefore must be hereby marked advertisement solely to indicate this fact. to $7 \mathrm{~mm}$ and at least one-fourth of the shoots were vitrified. Although fewer shoots were produced from explants incubated on media supplemented with $2 \mathrm{iP}$, these shoots grew much longer, i.e., 15 to $30 \mathrm{~mm}$, with little or no incidence of vitrification.

In one trial, stunted basal shoots were excised from shoot clumps after 3 to 4 weeks of incubation on multiplication medium with $0.5 \mu \mathrm{M} \mathrm{BA}$. Twenty-five shoots were placed on half-strength MS medium without plant growth regulators but supplemented with $0.04 \% \mathrm{w} / \mathrm{v}$ activated, neutralized charcoal. Twenty-one shoots were placed on halfstrength MS medium supplemented with 1 $\mu \mathrm{M}$ of gibberellic acid $\left(\mathrm{GA}_{3}\right)$. Both media suppressed further shoot multiplication and allowed shoots to elongate from two to four times their original length; however, medium supplemented with charcoal resulted in green robust shoot development compared with the yellowish-green, thin shoots produced in the presence of $\mathrm{GA}_{3}$.

Shoots 15 to $30 \mathrm{~mm}$ long were tested for root initiation on half-strength MS medium supplemented with auxin $(1,5$, and $10 \mu \mathrm{M}$ IBA) and as microcuttings using softwood cutting powder (with $0.01 \% \mathrm{w} / \mathrm{w}$ available IBA) applied to the base of shoots. Rooted and nonrooted shoots were acclimatized before removal from culture by transferring culture vessels to the glasshouse with $70 \%$ shade for several days. An initial potting mixture drench with $0.15 \%$ aqueous propyl[3-(dimethylamino) propyl] carbamate (propamocarb) antifungal solution was used. Microcuttings were placed initially in trays
Table 2. Percentage of Stirlingia latifolia shoots producing roots in vitro and in vivo, in response to auxin ${ }^{2}$.

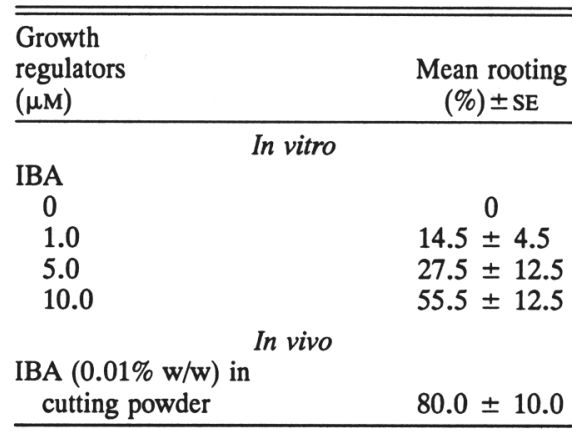

2Per 7-week incubation. Treatments replicated 20 times each, repeated twice, and results pooled.

of pots of 40-ml capacity (64 per tray) and grown in constantly fogged conditions until roots were formed, then moved to intermittent misting. In vitro rooting (Table 2) was not satisfactory; roots tended to grow from basal callus. Such shoots performed poorly when potted, possibly as a result of incomplete vascular connections and some unavoidable damage to roots on removal from agar and during transfer to potting mixture. In contrast, $>90 \%$ of unrooted shoots survived the transfer to pasteurized peat : perlite $(\mathrm{v} / \mathrm{v})$ potting mixture, and $80 \%$ of these shoots produced roots after 7 weeks (Table 2). Growth of microcuttings was healthy with plants 20 to $30 \mathrm{~cm}$ high 9 months after tansplanting from culture and flowering within a further 3 months under standard nursery conditions.

Micropropagation of S. latifolia should help limit the undesirable practice of bush picking and result in improvements in the quality and availability of this important species for commercial horticulture production.

\section{Literature Cited}

Burgman, M.A. and S.D. Hopper. 1982. The Western Australian wildflower industry 198081. Rpt. no. 53. Dept. Fisheries and Wildlife, Perth, Western Australia.

Murashige, T. and F. Skoog. 1962. A revised medium for rapid growth and bioassays with tobacco tissue cultures. Physiol. Plant. 15:473497.

Table 1. Shoot production per explant of Stirlingia latifolia placed on half-strength MS medium supplemented with $2 \mathrm{iP}$ or $\mathrm{BA}^{\mathrm{z}}$.

\begin{tabular}{|c|c|c|c|c|c|}
\hline \multirow{2}{*}{$\begin{array}{l}\text { Growth } \\
\text { regulators } \\
(\mu \mathrm{M})\end{array}$} & \multicolumn{4}{|c|}{ Frequency of shoots/explanty } & \multirow{2}{*}{$\begin{array}{c}\text { Mean no. } \\
\text { shoots/explant } \pm \text { SE }\end{array}$} \\
\hline & $1-3$ & $4-6$ & $7-9$ & $>9$ & \\
\hline \multicolumn{6}{|l|}{$2 \mathrm{iP}$} \\
\hline 0 & 100 & 0 & 0 & 0 & $1.1 \pm 0.1$ \\
\hline 2.5 & 50 & 45 & 5 & 0 & $3.6 \pm 0.3$ \\
\hline 5.0 & 0 & 35 & 65 & 0 & $6.9 \pm 0.3$ \\
\hline \multicolumn{6}{|l|}{ BA } \\
\hline 0.5 & 0 & 5 & 40 & 55 & $10.2 \pm 0.5$ \\
\hline 1.0 & 0 & 0 & 0 & 100 & $13.9 \pm 0.5$ \\
\hline
\end{tabular}

2Per 5-week incubation period. Treatments replicated 20 times each, repeated twice, and results pooled. yPercent of total in each category. 